in nature. Mental force is the capacity of material particles to act upon each other. The mental phenomenon is the performance of this action, which consists in motion, therefore in a change of position, of the material particles and the forces inherent in them, and by this leads directly to a new mental occurrence. Thus the same mental chain encircles all material phenomena.

The human mind is nothing else but the highest development upon our earth of the mental phenomena which move and animate nature everywhere. But it is not the product of secretion of the cerebral substance; as such it would be withont further influence upon the brain, just as the secreted gall is of no further signification for the liver. On the contrary, sensation and consciousness have their firm seat in the brain, with which they are indissolubly united, and in which, by their intervention, new conceptions are formel and converted into actions. Just as the stone would not fall down if it did not feel the presence of the earth, so the trampled worm would not wriggle if it had no sensation, and the brain would not act reasonably if it had no consciousness.

This conception satisfies our causal demands entirely. For the naturalist it is a logical necessity to admit only differences of degree in finite nature. In the same way as there is a common measure for everything in space as well as for everything in time, so there must be a common measure for all mental phenomena. In the same way as there are gradations in material nature from the most simple to the most complex, so there must be similar gradations in mental nature, which is parallel to the former. It is true that in atoms and molecules we do not yet find pleasure and pain or love and hate pronounced with decision, but yet we find the first germs, as it were the original beginnings, of these feelings, and it would be the task of a comparative psychology to follow consciousness through unconscious sensation down to the insensible action of material particles.

But the domain of the mind offers far greater difficuities to our investigation than the matcrial domair, because we can only use our subjective perceptions as immediate experience, and because we do not possess a special organ of sense which enables us to make objective observations of other bodies. The obser. vation with our senses, which are organised for quite different objects, acquaints us only in a roundabout way and in a very defective manner with the mental occurrences in other beings, and our judgment of them is all the more uncertain the further we depart in nature from the human species itself. It will therefore, perhaps, never be possible to find the measure for the mental phenomena really, to determine it, and to raise compara: tive psychology to the rank of a natural science.

Natural knowledge remains limited to what is finite, the naturalist must therefore confine himself strictly to the finite only. The demand, which is often addressed to him, that he should have a more philosophical mind, that he should criticise in a philosophical manner, because it is impossible to avoid metaphysical speculation entirely, only shows how difficult it is to separate two absolutely different domains, which have once been mixed up only to produce general confusion. The power of education and habit also was, up to the most recent period, an obstacle in the way of a complete and radical separation of these two domains, and yet it is certain, and we know by experience, that every metaphysical addition turns natural science and natural inve stigation into a turbid and muddy alloy.

Natural science must be exact ; it must rigialy avoid evergthing which oversteps the limit of the finite and the intelligible, and which is transcendental; it must proceed in a strictly materialistic manner, because its sole object is finite, forceendowed matter; and it must not forget that this true materialism is an empirical and not a philosophical one, and that it is bounded by the same limits as those of the domain upon which it moves.

I do not wish to say by this that the naturalist is not allowed to philosophise, that he is forbidden to move in ideal and transcendental domains. But he ceases to be a naturalist, and the only thing, which from his vocation is perhaps of advantage to him, is that he keeps both domains strictly apart; that he knows how to treat the one as the pure domain of investigation and knowledge, and the other, while he frees it from everything that is finite, as the hidden domain of presentiment.

To the human mind, to our desire of investigation and knowledge, the whole sensually-perceptible world is open. We penetrate into the greatest distances by means of the telescope and calculation, and into the smallest spaces by means of the microscope and combination. We investigate the most complex and complicated organism, which belongs to ourselves, in the most varied directions. We recognise the forces and laws governing nature, and through this we subject the whole inorganic and organic world, as far as we can reach it. If man reviews the triumphs in the domains of science and power which have been obtained up to the present, and thinks of the still greater future conquests, then he may with pride feel himself lord of the world.

But what is this world, over which the human mind reigns? Not even a grain of sand in the eternity of space, not even a second in the eternity of time, and only an outwork of the true essence of the universe. Because even of the infinitesimal world, which is accessible to us, we only know what is changeable and perishable. All that is eternal and stable, the how and the wory of the universe, remains for ever incomprehensible to the human mind, and if it tries to overstep the limit of finiteness it can only puff itself up to a ridiculously-adorned idol, or desecrate the eternal and the divine by human disfiguration. Even the matured mind, which would have arrived at complete natural scientific insight, and would wish to free the divine of everything finite and perishable, could, in its restriction, make of divinity only a constitutional phantom-king, who, according to the words of a statesman recently deceased, would "reign, but not govern." In the finite world the eternal natural forces rule unalterably, and we recognise their effects in the laws of motion and change. Whether and how they are the tenor and expression of a conscious eternal design is past our comprehension.

If my predecessor, Prof. Du Bois Reymond, ended his address with the crushing words, Ignoramus, et ignorabimus, then I close mine with the conditional but more consolatory utterance that we do not merely know, but really understand the fruits of our investigations, and that our knowledge bears in itself the germ of an almost infinite growth, without, however, approaching omniscience by the smaliest step. If we practise reasonable resignation, if, as finite and perishable human beings, as we are, we are satisfied with human insight, instead of claiming divine knowledge, then we may say with full confidence-

$$
\text { "We know, and we shall know!" }
$$

\section{ON THE SOLAR ECLIPSE OF AGATHOCLES}

$$
\text { B.C. } 3 \text { IO (15th August). }{ }^{1}
$$

THE mean motion of the moon round the earth was formerly assumed to be constant, until Halley showed that it has been gradually increasing by a small amount during the last few thousand years. Halley made this discovery by the study of ancient solar eclipses, which were found always to occur to the eastward of their calculated places :-this indicates a slower mean motion of the moon in former times, as may be thus shown-a spectator in the northern hemisphere looking at a solar eclipse will face the south, having the west on his right hand, and the east on his left hand; and he will see the moon cross the sun's disc from right to left. When we calculate backwards to an old eclipse (attributing to the moon her present mean motion), we are, in fact, unwinding, from left to right, the path she has described since the eclipse happened, and by this unwinding process we find that we always place the moon to the right (zvest) of the place where she was actually when the eclipse occurred. Thus, all the ancient eclipses being observed at places to the eastward (left) of their calculated places of observation, we learn that the moon's mean motion was formerly slower than it now is The coefficient of the moon's mean motion, found by Halley, from ancient eclipses, was

$$
10.2 \times n^{2},
$$

where $n$ is the number of centuries.

The acceleration of the moon's mean motion was first explained by Laplace, who showed that the mean central disturbing force of the sun, by which the moon's gravity towards the earth is diminished, depends not only on the sun's mean distance, but on the eccentricity of the earth's orbit. This eccentricity has been diminishing for many ages, while the mean distance remains unaltered. In consequence of this, the sun's mean disturbing force is diminishing, and, consequently, the attraction of the moon towards the earth has been increasing, and with it, of course, the mean motion of the moon has been also increasing. The calculations of Laplace, confirmed and extended by Damoiseau

I Paper read before the Mathematical Section of the British Association, Plymouth, I877, by Rev. Dr. Samuel Haughton, F.R.S. (Trin. Coll. Dublin.) 
and Plana, gave a coefficient for the moon's mean motion agreeing with that found from observation by Halley.

This satisfactory agreement between theory and observation remained unchanged until 1853 , when Adams announced 1 that he had found a deficiency in Laplace's calculation, arising from the fact that Laplace had considered the radial disturbing force only, and had neglected the tangential disturbing force.

When the fuller computation is made, it is found that the coefficient of Halley's expression is reduced from IO' 2 to $6 . \mathrm{II}$, leaving 4.09 not accounted for.

Adams' calculations were verified by Delaunay, who found them quite correct, and who had the merit of suggesting the explanation of the $4^{\circ} 09$, which form a residual phenominon. According to Delaunay, this uncompensated portion of Halley's cocfficient is to be explained by the retardation of the earth's angular velocity, and consequent increase in the length of the day, caused by the residual tidal current seting constantly from east to west. This residual current, alchougk excessively small, is a vera causa always acting, and must, in due course of time produce a sensible effect in lengthening the day. It is easy to show that the effect of the lengthening of the day upon ancient solar eclipses acts in the same direction as the acceleration of the moon's menn motion, viz., it throws the place of observation to the eastward (left) of the calculated place ; for the earth moves from rigbt to left, in the same direction as the moon, and as its rotation in that direction, from the period of the eclipse, has been greater than that assumed in our calculation from the present rotation of the earth, it follows that, at the time of the eclipse, all places on the earth's surface must have been absolutely, with reference to a meridian fixed in space, to the westward (right) of their present positions. According to this view, therefore, the displacement eastwards of the places of observation of ancient eclipses, when compared with the calculated places of observation, is the sum of two displacements-one caused by not allow-

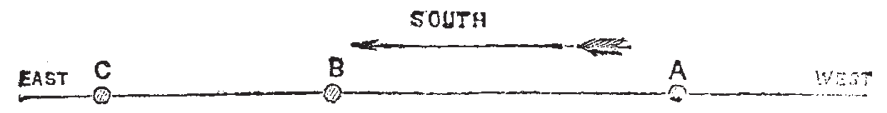

ing for the accileration of the moon, and the other caused by not allowing for the retardation of the carth.

Thus, if 13 represent the true position of the eclipse in space, its calculated place will be $A$, to the west of $B$, the interval $A B$ being due to the neglect of the acceleration of the moon's mean motion (with coefficient $=6.11$ ) in the calculation; and the point exactly below $\mathrm{B}$, on the earth's surface, will have moved on to $C$, to the east of $B$, in consequence of the neglect of the retardation of the earth's rotation in the calculation.

Let us illustrate the case by one of the most famous solar eclipses on record, that of Agathocles, on August 15, 310 B.C. The accompanying outline map represents the course taken by the expedition of Agathocles from Syracuse to Carthage. ${ }^{2}$

:-This eclipse is recorded by Diodorus Siculus, and has been always considered one of the most important in support of Halley's coefficient, $10 \cdot 2$ seconds.

It has recently, however, been called in question by a high

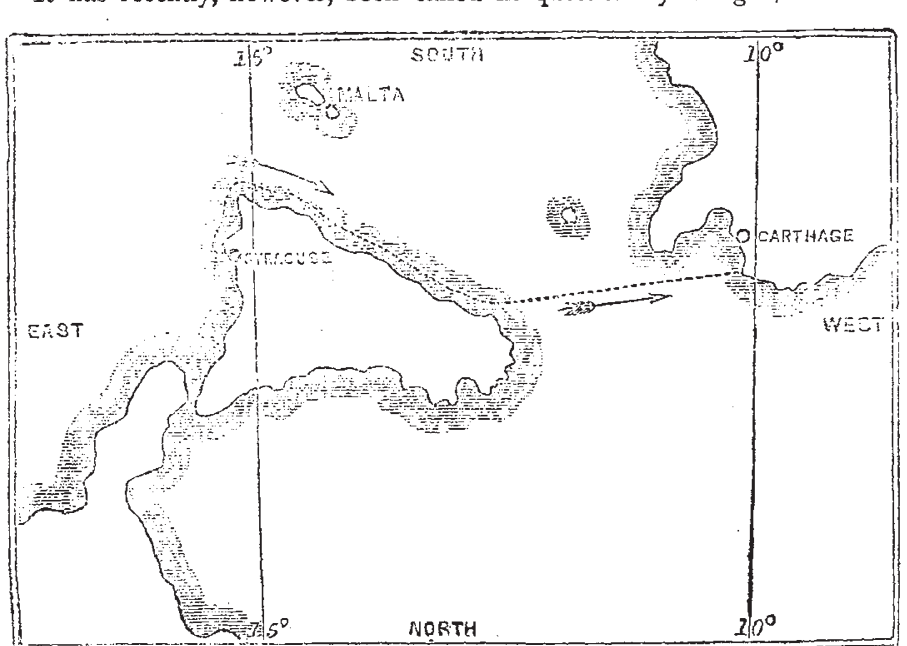

on the record of ancient eclipses. Prof. Newcomb considered these eclipses separately. The most pronising of the Greek solar eclipses was that of A sathocles, tyrant of Syracuse, occurring at the commenconent of his voyas to attack Carthage. But we do not know on which side of Sicily he sailcd: according to whether he was on one or the other sidle of the coast, the difference of time for that eclipse may be calculated as justifying the ro seconds or the 6 seconds accleration of the moon. The eclipse known as that of Thales has a record still more open to criticisni, because it came to its historian by hearsay, and probably through two or three generations after the lapse of a hundred years. It seems curious that if Thales predicted the year (by an estimate of lunar periods) he did not also predict the day. Each of the ancient solar eclipses yielded similar elements of doubt, on careful examination. From the records of lunar eclipses, if all unccrtain features be weeded out, the old estimate of acceleration will be reduced one-half. in records of lunar eclipses were published at Leyden
in the early part of this century. The work is very rare. Altitudes of sun and moon are constantly given in it. Calculations from these eclipses give the smaller estimate of acceleration. From all the data he has been able to study, Prof. Newcomb con. cludes that the whole amount of acceleration is about $\delta^{\circ} 4$ seconds. He hopes to make further estimates from modern records, having had the good fortune to pick up in Paris carefully compiled data of occultations going back to 1680 ."

Let us compare this statement of Prof. Newconb with the original account of Diodorus Siculus. Agathocles was blockaded in Syracuse by the Carihaginian fleet, and the town was in danger of starvation; under these circumstances he formed and carried out the daring project of breaking the blockade, and undertaking an expedition by sea against Carthage itself; which he successfully accornplished. Diodorus says : "But Agathocles, thus overtaken and sur. rounded, hit upon an unexpected chance of escape when night came on; and on the following day there came to pass so great an eclipse of the sun that night appeared universally, the stars being seen in every direction; wherefore the people of Agathocles, believing that the Divinity foreshadowed some evil to happen them, were in still greater anxiety of mind than before. When they had voyaged for six days and as many nights, at the dawn of day the fleet of the Carthaginians appeared unexpectedly, not far off. . . . But when Africa came

Ortygiam. Alpheum fama est huc Elidis amnem

Occultas egisse vias subter mare : qui nunc

Ore, Arethusa, tuo Siculis confundiur undis.

Jussi numina magna loci veneramur: et inde Exsupero prapingue solum stagnantis Helori, Hinc altas cautes projectaque saxa Pachyni Radimus, et fat.s nuequam concessa mover Adparet Camarina procul campicue Geloi, Inmanisque Gela fluvii cognomine dicta, Arduus inde Acragas ostentat maxima longe Mœnia maguanimum quondam generator equorum, Teque datis linquo ventis, palmosa Seliats ; Fit vada dura lego saxis Ijlybeia cacis, Hinc Drepani me portus et inletabilis ora Adcipit. $-A_{N}$., Lib, xir., $69 z-708$. 
in sight, an incredible exhortation to the rowers and rivalry took place. The ships of the barbarians indeed went faster, because for a length of time they had been accustomed to the handling of the oars; but the ships of the Greeks preceded them by a small interval; and, having finished their voyage as quickly as possible, they immediately sprang upon the strand like wrestlers; and, indeed, the leading ships of the Cartbaginians attacked the aftermost ships of Agathoc? es, having come within range of missiles." -Diod. Sic., lib. xx., ch. $5,6$.

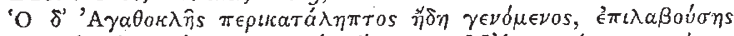

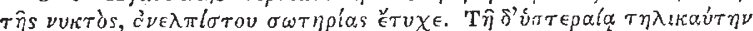

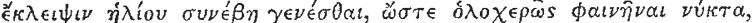

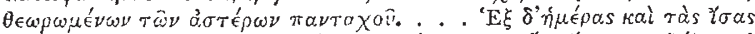

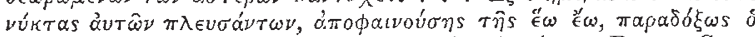

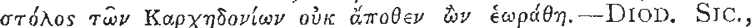
Lib. $x x$., ch. 5 , 6 .

From this narrative it can be clearly shown that Prof. Newcomb is mistaken when he says that "we do not know on which side of Sicily he sailed." It is quite certain that the eclipse occurred before the expedition had weathered the promontory of Pachynus, or had made any sensible westing in their voyage.

The total distance, on a coasting voyage from Syracuse to Carthage, is $35^{\circ}$ English miles, and the distance from Syracuse to Cape Pachyius is forty miles. Now, the whole time of the voyage was six days and as many nights, together with a portion of a night at Syracuse, and a portion of a day near Carthage (the stone quarries). Allowing six hours each to these, we have :-
Part of night of outset at Syracuse

Part of day near Carthage before landing at the "Stone Quarries"
Six days and as many nights ...

\section{Hours.}

144

6

I 56
This is the minimum time allowable from the narrative, and any longer time allowed will strengthen my argument. The rate of rowing during the voyage was, therefore,

$$
\frac{350}{156}=2 \cdot 25 \text { miles per hour. }
$$

At this rate of rowing it would require $17 \mathrm{~h} .48 \mathrm{~m}$, to reach Cape Pachynus, a distance of forty miles; so that if the expedition sailed at midnight, it would have been off Pachynus, to the eastward, at 5 P.M., which is the time assigned by Petavius for the middle of the eclipse (Syracusan time). It is, therefore, perfectly clear that if the expedition had got so far to the westward as to allow of the cosfficient $(6 \cdot 11)$, the eclipse must be thrown into the wrong day, which is inadmissible.

If Delaunay is to be trusted, the expedition must have gone out of the Mediterranean into the Atlantic before the coefficient 6.1 I could be verified. He says:- "Nous avons dit que la durée du jour augmentait d'une seconde dans l'espace de 100,000 ans. Mais cela se produit progressivement, de telle manière que ces augmentations successives des jours s'ajoutent, et au bout d'un grand nombre de jours, font un total appréciable. Si on remonte à une époque, de 2400 ans époque à peu près, à laquelle on rapporte les éclipses historiques dont on a parlé, on voit que l'observation de l'une de ces éclipses a dû être faite $\mathbf{I}^{\mathrm{b}} \frac{3}{4} \mathrm{f}$ plus tôt que si le ralentissement du mouvement de rotation de la terre n'avait pas existé.

"La variation relative aux anciennes éclipses va donc jusqu'à $1^{\text {b3. }}$ Ainsi une éclipse a été observée à un certain moment $I^{\text {hiz }}$ plus tôt qu'elle ne l'aurait été sans le ralentissement.

"Prenons les trois éclipses principales rapportées par l'histoire. Celle de Thalès, arrivée 585 ans avant J.-C., a été vue en Asie Mineure; sans le ralentissement du mouvement de rotation de la terre, on l'aurait vue dans l'ile de Sardaigne.

"Celle de Darisse (557 ans avant J.-C.) a été observée en Perse; on l'aurait vue dans la régence de Tripoli, sans le ralentissement.

"Enfin, celle d'Agathocle ( 3 ro ans avant J.-C.), signalée près de Syracuse, aurait dû se montrer près de Cadix." 1

\section{STRIDULATING ORGANS IN SCORPIONS}

$A \mathrm{~T}$ the September meeting of the London Entomological A Society, Mr. J. Wood-Mason announced the discovery of tridulating organs in scorpions. While recently working at the anatomy of a species allied to S. afer, he had met with structures which, from his familiarity with the analogous ones in other arthropods, crustaceans as well as insects, he had at once without hesitation determined to be sound-producing apparatuseven before he had found that sounds could be produced by them artificially by rubbing the parts together or accidentally in the mere handling of alcoholic specimens. He had, however, been enabled to place the matter beyond all doubt, for while at Bombay waiting for the steamer, he had obtained, by a happy chance, from some Hindustani conjurors, two large living scorpions belonging to another species of the same type; these, when fixed face to face on a light metal table and goaded into fury, at once commenced to beat the air with their palps and simultaneously to ernit sounds which were most distinctly audible not only to himself, but also to the bystanders, above the clatter made by the animals in their efforts to get free, and which resembled the noise produced by continuously scraping a piece of silk woven fabric, or, better still, a stiff tooth-brush with one's finger-nails. The species-a gigantic one from the Upper Godaveri district--in which he had first observed stridulating organs, had these organs more highly developed than in the one experimented upon at Bombay, and must stridulate far more loudly, for by artificially rubbing the parts together in a dead alcoholic specimen he could produce a sound almost as loud as, and very closely similar to, that made by briskly and continuously drawing the tip of the index-finger backwards and forwards in a drection transverse to its coarse ridges, over the ends of the teeth of a very fine-toothed comb. The apparatus, which, as in the Mysale, is developed on each side of the body, was situated-the scraper upon the flat outer face of the basal joint of the palp.fingers; the rasp on the equally flat and produced inner face of the corresponding joint of the first pair of legs. On separating these appendages from one another, a slightly raised and well-defined large oval area of lighter coloration than the surrounding chitine was to be seen at the very base of the basal joint of each ; these arex constituted respectively the scraper and the rasp; the former was tolerably thichly but regularly beset with stout, conical, sharp spinules curved like a tiger's canine, only more towards the points, some of which terminate in a long limp hair; the latter crowdedly studded with minute tubercles shaped like the tops of mushrooms. He had met with no stridulating organs in this position in any scorpions besides $S$. afer and its allies; but in searching for them in other grouns he had come to the conclusion that the very peciliar armature of the trenchant edges of the palp-fingers in all the Androctonoida, and in some at any rate of the Pundinoike (no Teleronoide or $V^{*}$ jovoide had yet been examined), was nothing but a modification for the same purpose, for the movable finger of this pair of appendages when in the closest relation of apposition to its immovable fellow could most easily be made to grate upon it from side to side so as to produce a most distinct crepitating sound; but when separated from it ever so little appeared to be incapable of the slightest lateral movement. It was his intention on his return to India to endeavour to determine this question, as well as many others relative to the species in which the presence of sound-producing apparatus had now been demonstrated by careful observation and experiment upon living animals.

\section{UNIVERSITY AND EDUCATIONAL INTELLIGENCE}

OxFord, - Mr. Thomas Whittaker, from the Royal College of Science, Dublin, has been elected to a Natural Science Scholarship at Exeter College.

At Jesus College the following elections to Welsh scholarships have been made :--In mathematics, Mr. David Davies, from the College, Llandovery; in science, Mr. William Williams, from Dolgelly Grammar School.

The Commissioners commenced their sittings at the Clarendon Hotel on Monday. The proceedings of the Commissioners were of a formal character, but Tuesday, it was understood, they would proceed to take evidence.

CAMBRIDGE. - The master and seniors of Gonville and Caius College will proceed in Decenber to elect a prælector in chemistry, in succession to the late Mr. Richard Apjohn. The duties of the prelector will be to take charge of the college laboratory, to prosecute original research, to instruct in chemis- 